\title{
WAR IN THE SOUTHWEST, WAR IN THE WORLD
}

\author{
Stephen H. Lekson
}

\begin{abstract}
The study of warfare in the ancient Pueblos of the U.S. Southwest has become politicized and contentious, and southwestern data are only rarely used to address larger anthropological theories of war. A cross-cultural model of violence proposed by Carol and Melvin Ember (1992) suggests that war in pre-state societies is predicted by resource unpredictability and socialization for fear. The Ember and Ember model is evaluated using syntheses of southwestern warfare by Steven LeBlanc (1999), environmental variability by Jeffrey Dean $(1988,1996)$, and political history by Stephen Lekson (1999). The fit between the southwestern data and the model is close, and supports the Ember and Ember model.
\end{abstract}

El estudio de la guerra entre los Pueblos antiguos del Suroeste de los Estados Unidos se ha vuelto politizado y contencioso, y los datos del Suroeste han sido usados raramente para tratar las teorias antropológicas mas extensas sobre la guerra. Un modelo transcultural de violencia propuesto por Carol y Melvin Ember (1992) sugiere que la guerra en sociedades pre-estatales es predecible por la incertidumbre de los recursos y la socialización por miedo. El modelo de Ember y Ember es evaluado usando la sintesis de la guerra en el Suroeste por Steven LeBlanc (1999), la variabilidad del medio ambiente por Jeffrey Dean (1988, 1996), y la historia política por Stephen Lekson (1999). La estrecha concordancia entre los datos del Suroeste y el modelo apoya la propuesta de Ember y Ember.

$\mathrm{T}$ The past decade has seen renewed archaeological interest in warfare in the ancient U.S. Southwest (Haas 1990; Haas and Creamer 1993; LeBlanc 1999; Lipe 1995; Rice and LeBlanc 2001; Schaafsma 2000; Turner and Turner 1999; Wilcox and Haas 1994). A region conventionally considered peaceful is emerging as periodically violent. Southwestern warfare receives media attention, and, in its most sensational presentations (Preston 1998; Turner 1999), accounts of warfare and possible cannibalism polarize archaeology and offend Native Americans. The furor caused by journalistic presentations of these subjects, however, does not diminish their importance. As Haas (1990), Kantner (1999), LeBlanc (1999) and, earlier, Kroeber and Fontana (1986) have demonstrated, the study of violence in the ancient Southwest can contribute to larger anthropological questions about warfare.

There is, of course, no anthropological unanimity on war's causes (see, for example, Ferguson 1984; Ferrill 1997; Haas 1990; Keeley 1996; Kelly 2000; Otterbein 1973, 1997; Reyna and Downs 1994). If consideration is extended to other disciplines that study warfare (economics, history, military science, political science, philosophy, psychology, sociology, and others), the range of ideas is staggering. Many theories about warfare fall into two major approaches: ideas that favor internal biological or psychological causes, and ideas that favor external institutional or environmental causes. Arguments from either perspective are often presented as exclusive: that is, external or internal factors are presented as paramount. In this paper, I will use southwestern prehistoric data to evaluate one cross-cultural study that links the origins of warfare to both external environmental and internal psychological factors, developed by Carol Ember and Melvin Ember (1992).

In the Ember and Ember model, the primary external environmental factor is resource unpredictability. Is resource unpredictability correlated with southwestern war? The southwestern data used here to evaluate warfare and resource unpredictability are, principally, Steven LeBlanc's (1999) recent summary of violence in the Southwest and Jeffrey Dean's dendroclimatological reconstructions of ancient southwestern climate (Dean 1988, 1996). A secondary factor in Ember and Ember's study implicates internal psychological conditions with the onset or

Stephen H. Lekson $~=$ Department of Anthropology and Museum of Natural History, University of Colorado, Boulder, CO 80309-0218 
prevalence of warfare. This factor is socialization for mistrust or fear. My reconstruction of the political history of the ancient Southwest (Lekson 1999) will be used to evaluate Ember and Ember's second, internal proposition about the causes of war.

The Ember and Ember study is particularly interesting in that it addresses both external, environmental causes and internal, psychological causes. It is only one alternative in the vast literature on war, but Ember and Ember's cross-cultural methodology is singularly well-suited to archaeological application and testing (Ember and Ember 1995).

The southwestern studies that form the core of my analysis are subject to various and numerous criticisms, but these works provide remarkably (even uniquely) broad syntheses of key themes useful for the evaluation of the Ember and Ember model. Wide-ranging synthetic studies-such as those of LeBlanc and my own work - are always vulnerable to alternate interpretations of details and particulars; but, as we shall see, the conclusions of the studies I use here are remarkably congruent. The mutual agreement of these independent studies must not be accepted uncritically as representing a true interpretation of the past, but their complementarity is heartening.

This article is not an attempt to develop an encompassing model for violence and warfare in the Southwest. It is only an application of the Ember and Ember model to southwestern data-no more and no less. Nor does it present startling new data; the data considered here come from published, peerreviewed studies, cited and quoted throughout. The paper begins with a brief review of relevant southwestern prehistory. It then summarizes Ember and Ember's study of warfare in non-state societies, and their conclusions linking (primarily) environmental factors and violence and (secondarily) psychological factors and violence. Dean's dendroclimatology and LeBlanc's study of warfare in the ancient Southwest will then be presented to evaluate the environmental aspects of the Ember and Ember model. My version of Pueblo political history is then integrated with chronologies of violence and warfare to address the psychological conclusions of the Ember and Ember study.

A particular appeal of the Ember and Ember model for southwestern archaeology is this: it works. As we shall see, there is a reasonably good fit between their model and our data. That fit, of course, is no reason to ignore imperfections in either the model or the data, but it happens so seldom that it seems worthy of remark.

\section{The Southwest, In Brief}

The archaeology of Pueblo peoples is well summarized by Cordell (1994, 1997), Plog (1997), and Reid and Whittlesey (1997). Here I provide an extremely brief version of later Pueblo history and geography, for readers who may be unfamiliar with the region. This paper does not address the Hohokam (the ancient peoples of southern Arizona), and they are absent from this review. Note that all dates in this paper are A.D.

Southwestern archaeology is doubly fortunate in that it has a great deal of high-quality field research and high-resolution dendrochronology, which provides both precise tree-ring dates and (as discussed below) fine-grained climatic data. The prehistory of the Southwest is also relatively uncomplicated, in contrast to the Basin of Mexico, the Tigris-Euphrates, or many other areas with longer sequences and more complex developments. The Southwest provides a simple and relatively clear archaeological record. This is not to diminish the remarkable achievements of ancient southwestern peoples (or modern archaeologists); indeed, the Southwest's simplicity and the quality and quantity of its archaeological data make the Southwest a useful place for investigating complicated matters, and war is a complicated matter.

Today, Pueblo peoples live in about 30 towns in 19 tribal clusters, along a 500-km-long arc from the Hopi villages of Arizona to Taos Pueblo in New Mexico (Figure 1). The modern Pueblo groups are the cultural heirs of a tradition of small farming villages that reaches back in time at least 1,500 years, and extended in space over the "Four Corners" areas of Utah and Colorado, most of New Mexico and Arizona, and the northern part of Chihuahua. It is useful to divide this vast area into northern and southern parts (Figure 1). The northern half of the Pueblo region corresponds, roughly, to the southern portion of the Colorado Plateau and includes the present Pueblos. The southern half includes the mountainous Mogollon uplands and the upper margins of the Sonoran and Chihuahuan deserts. Most towns in the southern Pueblo world had been abandoned about 1450 , but at the time of Spanish contact, Pueblo peoples were living in the northernmost reaches of the Chihuahuan deserts in south-central New Mexico. 


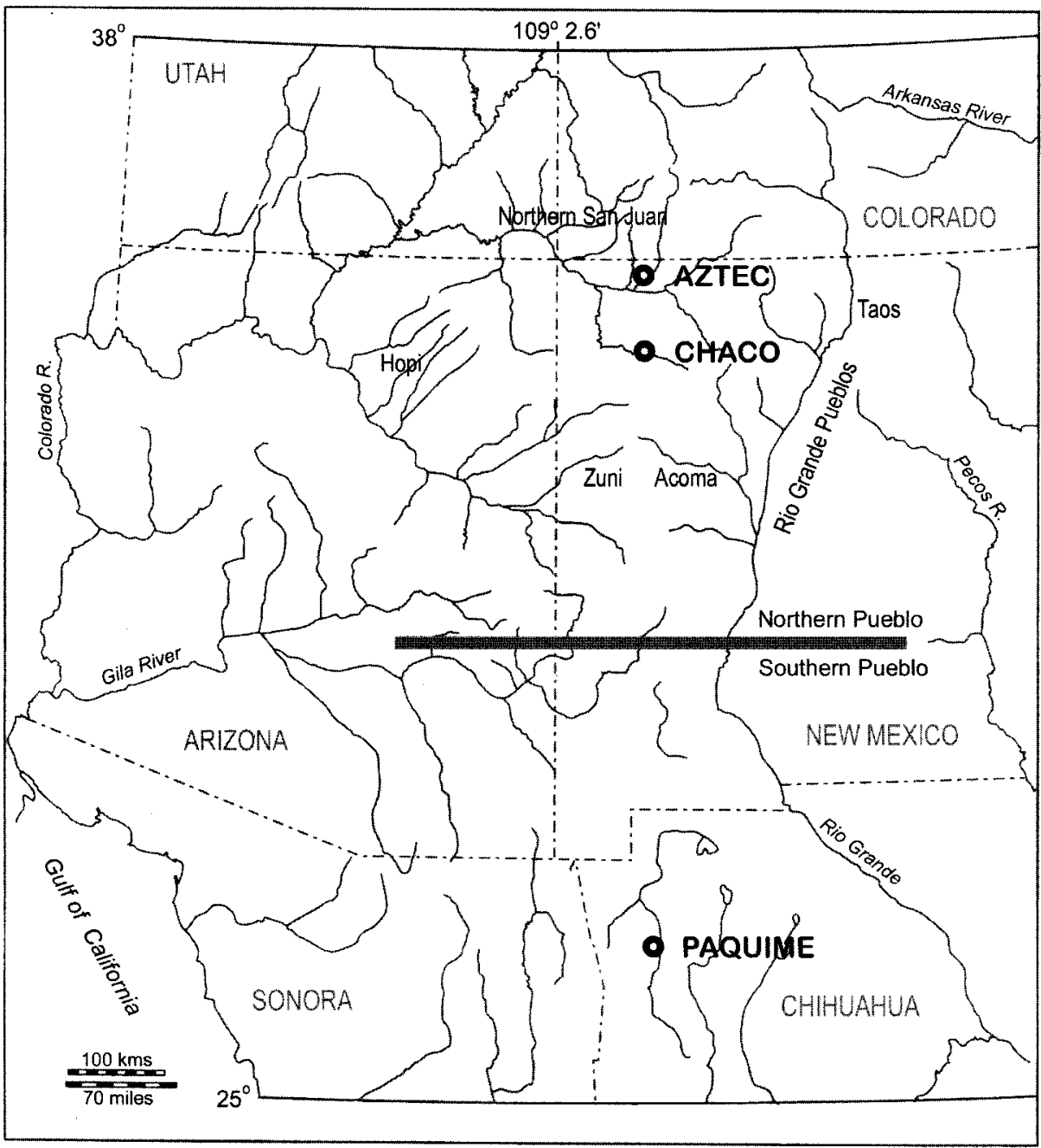

Figure 1. Southwest United States and Northwest Mexico, with selected towns, sites, and regions.

Those southern villages did not survive colonization. The entire region is arid. Agriculture in the south was closely linked to rivers and canal irrigation, but "dry farming" (relying primarily on rainfall) was a major element of subsistence in the northern Pueblo world.

Pueblo traditional histories recount high degrees of population movement and migrations by large groups. Many pueblos grew to several thousands of residents by the fifteenth and sixteenth centuries, despite the "abandonment" of the Four Corners area at the end of the fourteenth century, the "abandonment" of the southern Pueblo region in the fifteenth century, and other population disruptions.

Various areas within the Pueblo world were archaeologically prominent at different times. Chaco
Canyon was very important in the tenth and eleventh century. For over a century, archaeologists explored and excavated at Chaco (Frazier 1999; Lister and Lister 1981). Judge (1989) provides a particularly useful summary, and I follow his chronology here (see also Crown and Judge 1991; Lekson et al. 1988). Chaco's massive buildings and its remarkable network of "roads"- -linear earthen features that extend great distances-and far-flung Chaco-like structures ("outliers") have suggested to many archaeologists that Chaco was the center of a large region.

Chaco's end in the early or mid twelfth century was followed by the rise of remarkable cliff-sheltered villages in southwestern Colorado and across the Four Corners area. The cliff-dwellings date principally to the late twelfth and thirteenth century. The 
largest villages of this era, however, were huge "open" sites that were up to five times the size of the largest cliff-dwellings. The twelfth and thirteenth centuries saw the emergence (or solidification) of localized traditions-“Kayenta," "Mesa Verde," "Tularosa," and the like-several of which continued down into the historic Pueblos. An excellent summary of the Pueblo world during this period is provided by Adler (1996).

One of the very largest thirteenth-century sites, discussed below, was the misnamed Aztec Ruins complex in northwestern New Mexico. The major excavations at Aztec Ruins were the work of Earl Morris; Morris's work was summarized in Lister and Lister (1987). Recent thinking is summarized by McKenna and Toll (2001). Aztec Ruins, during the twelfth and thirteenth century, included six-to-eight structures comparable to the massive Chacoan buildings of the preceding century and scores of smaller structures. Building ceased at Aztec Ruins about 1275 , a date coinciding with the "Great Drought" of ca. 1275-1300 and the final abandonment of the Four Corners region.

The fourteenth and fifteenth centuries saw the development of Pueblos along the Rio Grande, at Acoma, Zuni and the Hopi mesas, as well as significant population centers in the southern Pueblo area in the Mogollon uplands and northern Chihuahua. Many of these towns and village clusters emerged from local traditions; others were significantly affected by the late-thirteenth-century population movements out of the Four Corners area and (later, and less certainly) by fifteenth-century movements out of the southern Pueblo region. Sites reached very large sizes: the largest prehistoric Pueblos date to the fourteenth and fifteenth centuries. One of these is a site that is emerging as truly important in southwestern archaeology: Paquimé, near the town of Casas Grandes in Chihuahua, Mexico. Paquimé is only a little more than $100 \mathrm{~km}$ south of the international border, but southwestern archaeologists did not begin to understand the site until the late $1960 \mathrm{~s}$, when Charles Di Peso of the Amerind Foundation excavated about one-third of the ruin. His monumental report (Di Peso 1974) is the principal account of the site, supplemented by recent research (Schaafsma and Riley 1999; Whalen and Minnis 2001). The city of Paquimé was abandoned about 1450, along with much of the southern Pueblo world. The northern Pueblos continued to grow and flourish until the arrival of the Spanish in the late sixteenth century.

This brief survey, of course, does not attempt to digest the cultural history or the voluminous archaeology of the Pueblo Southwest. It simply outlines the chronology and geography of Pueblo prehistory, and introduces principal sites pertinent to the analysis of violence and warfare in the Southwest, to which we now turn.

\section{Cross-Cultural Studies of Warfare in Non-State Societies}

One of the most influential recent syntheses of warfare in non-state societies is Lawrence Keeley's (1996) War Before Civilization. Keeley makes a strong case that "archaeologists of the postwar period had artificially 'pacified the past' and shared a pervasive bias against the possibility of prehistoric warfare" (Keeley 1996:vii). In contrast to that received view, he argues that "peaceful prestate societies were very rare; warfare between them was very frequent" (Keeley 1996:174). Keeley's study documents the prevalence of war across a wide range of societies in a broad range of times, as a corrective to the vast literature on war that is based, he argues, on fatally insufficient data. Misunderstandings of the violent nature and high frequency of war in non-state societies have, in Keeley's opinion, undermined classical and contemporary theory on war. (See Otterbein 1997 for a critique of Keeley, and a more moderate reading of war in pre-state societies.)

The Pueblo Indians of the U.S. Southwest are famously peaceful. Pueblos of the late-nineteenth and early twentieth century were offered as models for nonviolent society (Benedict 1989[1934]). Was this always the case? Steven LeBlanc (1999) argues that Keeley's thesis applies to the U.S. Southwest: LeBlanc concludes that the ancient Southwest was as violent as other agricultural, non-state societies.

For Keeley, the theoretical search for causes of warfare is confounded by the complexity of the phenomenon, pervasive across many varied societies and different environments. The richness and variety of Keeley's data defeat the simple causal arguments of past theories: "the essential focus of almost all of these arguments has been the perennial question: what causes war? . . no complex phenomenon [such as war] can have a single cause" (Keeley 1996:17). Perhaps the Southwest, in its simplicity and archaeological clarity, will prove a useful place to investigate war's causes. I turn now to a study 
comparable to Keeley's in breadth, which reached tentative conclusions about the causes of war. These conclusions can be evaluated using southwestern data.

Carol Ember and Melvin Ember (1992; see also Ember 1982) conducted a broad cross-cultural study of the predictors of warfare in non-state societies, by evaluating standardized coefficients in a multiple regression analysis of cross-cultural data mostly from the Human Relations Area File Collection of Ethnography. They concluded, "war may be caused by a fear of nature and a partially resultant fear of others. A history of unpredictable natural disasters strongly predicts more war, as does socialization for mistrust (but less strongly)" (Ember and Ember 1992:242). That is, they concluded that two factors most strongly predicted the presence of war in non-state societies.

The two strongest predictors of warfare were "resource unpredictability" $(R=0.631, p<0.001)$ and "socialization for mistrust" $(R=0.352, p<0.025)$ (Ember and Ember 1992:Table 1). Resource unpredictability refers to "nonchronic resource problems created by natural disasters" (Ember and Ember 1992:250). Socialization for mistrust is a psychological result of enculturation: "people who grow up to be mistrustful of others, and who therefore fear others, may be more likely to go to war than to negotiate or to seek conciliation" (Ember and Ember 1992:245). They argue from their analysis that socialization for mistrust is "more likely a cause than a consequence of war" (Ember and Ember 1992:254). For reasons that will become clear, I recast "socialization for mistrust" as "socialization for fear."

Each of these factors will be discussed at more length below, but please review the Ember and Ember article for the larger arguments behind these two conclusions, which I accept here as hypotheses. Can we test these hypotheses with the archaeological record of the U.S. Southwest? I will first discuss resource unpredictability, and then turn to socialization for fear.

\section{Resource Unpredictability}

Resource unpredictability is a far more familiar theme in archaeology than socialization for fear. Rainfall farming (or "dry farming") was apparently the major agricultural strategy in the northern Pueblo region (Cordell 1997; Plog 1997; Reid and Whittlesey 1997). Absent investment in canal irrigation, rainfall was probably the most important environmental parameter that affected crop production through various "dry-farming" strategies. Salinated soils, unseasonable frosts, insect infestations, and other natural disasters undoubtedly impacted crops, but year-to-year, rainfall was probably the principal concern of farmers and their leaders. Today, much Pueblo ceremonialism encourages or insures rainfall.

Because of the very close linkage between precipitation and farming success, resource unpredictability should be reflected in dendroclimatology, the reconstruction of past climate through tree-ring analysis. Dendroclimatology provides annual and even seasonal projections of precipitation, with great precision. The remarkable dendroclimatological record in the Southwest was summarized in a widely cited paper by Jeffrey Dean (1988). Dean defined periods of "high temporal variability" in tree-ring departures (averaged decadally); that is, spans in which year-to-year variation was highly variable. Variation in tree-ring departures reflects comparably high temporal variability in various parameters of annual rainfall that, in the arid Southwest, has a direct relationship to crop production in "dry-farming" societies of the ancient Pueblo region (e.g., Van West 1996). In a later paper, Dean (1996) presents additional data on seasonal variation, that is, patterns of seasonal dominance of precipitation-a key factor in the success of "dry farming." In this section, I will briefly discuss conventional archaeological interpretations of environmental risk, and then use data from Dean's 1988 and 1996 papers to construct a chronology of resource unpredictability.

"High temporal variability," as presented by Dean $(1988,1996)$ is a composite measure, defined by visual inspection of a number of parallel tree-ring sequences. (Spatial variability is also important, but beyond the goals of my paper.) In periods of "high temporal variability," change from high to low treering indices was rapid, taking place over scales of one to ten years. "High temporal variability" was defined in contrast to "low temporal variability," when change took place over several decades. In short, "high temporal variability" meant rapid, shortterm oscillations of precipitation, while "low temporal variability" meant longer term, more stable regimes. Cultural systems could adapt to either circumstance - the principal argument of Dean and his colleagues (see chapters in Gumerman 1988).

Viewed from the longer term, southwestern societies did indeed adapt - by creating new storage technologies, intensifying agricultural practices, by 
migrating to new places, or by dissolving into new social tormations. These adaptations, while real, are best perceived from the distance of history: a pattern invisible to people when they lived it, and unknown to us before we detected it (to paraphrase Kubler 1962:13). But from the perspective of the individual farmer, living in the pattern "low temporal variability" must have been perceived as more predictable or more constant than regimes of "high temporal variability." In regimes of "low temporal variability," good times stayed good and bad times stayed bad. Subsistence decisions could be made with a reasonable degree of predictability. In regimes of high temporal variability, the only constant was change. A farmer would never know what the next year might bring, and any decision could easily be wrong. Risk - both real and perceived - was high.

It is possible to adapt to circumstance of high-temporal variability by developing storage, reciprocity, and other adaptationist scenarios (as Dean and others have demonstrated). It is also possible to respond to those circumstances by raiding and warfare, as Billman et al. (2000) and Haas and Creamer (1993) suggest for the Pueblo Southwest, or by developing a degree of political complexity, as Judge (1979) and Lekson (1999) have suggested for Chaco.

Southwestern archaeology has long favored storage, agricultural intensification, and other economic adaptations to environmental risk over political or power responses. A fair gauge of southwestern thinking can be found in the ten papers compiled in Evolving Complexity and Environmental Risk in the Prehistoric Southwest (Tainter and Tainter 1996). These studies address "resource uncertainty," "risk," and "subsistence stress" (all of which encompass various forms of resource unpredictability). Political hierarchy and warfare barely break the surface (most notably in Kohler and Van West 1996:183; and in Tainter's introduction to the volume), and are generally ignored as an alternative to adaptationist responses to environmental risk. Linda Cordell, in her concluding remarks to this important volume, notes the relative unimportance of political models:

Regional social dynamics and hierarchical systems of social control are not considered important to the kinds of strategies implemented in response to stress. . . . despite more than a decade of discussing the Chaco Phenomenon and the possibility of the existence of regionally based systems in the fourteenth century, most archaeologists are probably not convinced that these had any meaningful impacts on local behaviors [Cordell 1996:254].

In contrast, I will argue that regional political structures were major factors in management of risk and response to resource unpredictability in the ancient Southwest.

Resource unpredictability, as defined by Ember and Ember, includes natural disasters: volcanoes, floods, plagues of locusts, and other epic calamities. Resource unpredictability need not be quite so dramatic, particularly for marginal environments. In deserts, slight variations in rainfall can make the difference between subsistence success and failure. We are accustomed to think of risk in the ancient Southwest in terms of droughts. The Southwest is a desert; that is, drought is a constant. Sustained severe droughts with "low temporal variability" - such as the so-called Great Drought of ca. 1275-1300, could be accommodated by movement or by the development of new technologies, such as irrigation. That is, a series of dry years became predictable, and societies and individuals made decisions based on the perceived likelihood of another bad year. (Prolonged periods of higher rainfall were also, presumably, circumstances to which ancient societies could adjust, presumably with more satisfaction.) But rapid and effectively unpredictable oscillations between "wet" and "dry" years-Dean's periods of "high temporal variability" - would challenge conventional social responses and perhaps exceed existing strategies for subsistence adjustments.

Thus, Dean's periods of "high temporal variability" in tree-ring departures can be taken as proxy measures of resource unpredictability. Periods of "high temporal variability" as defined by Dean (1988:138) fall at approximately 310-380, 750-1000, 1350-1560, and 1730-1825. That periodization will be modified, slightly, here to reflect an additional form of unpredictability: seasonal variability of precipitation. Dean (1996) identified two basic regimes of seasonality. In the north and west Southwest, precipitation was generally "bimodal" (evenly divided between winter and summer), while in the east and south precipitation was "summer dominant" (Dean 1996:Fig. 5). Those patterns held over almost all the dendroclimatological record; that is, they were effectively predictable over long periods of time. At ca. 1250, however, those long-standing patterns were disrupted; that is, they became strikingly unpredictable. "Between about A.D. 1250 and 
$1450 \ldots$ the long-term pattern [of seasonal precipitation] broke down into chaotic distributions ... that exhibit no local geographic patterning" (Dean 1996:43). From 1250 to 1450 , the Pueblo people experienced resource unpredictability of a type unique in later southwestern prehistory: "a 200-year, regional-scale disruption of a climatic pattern that characterized the Southwest for the preceding 550 years [A.D. 700 to 1250] and the following 550 years [A.D. 1450 to present]" (Dean 1996:43; see also Ahlstrom et al. 1995). It should be noted that the analysis of seasonal variability was conducted by a principal component analysis of overlapped centuries, and therefore is potentially less precise than the decadal analysis of rainfall variability, discussed above. The onset date of 1250 is therefore approximate.

"High temporal variability" in tree-ring departures happened at least four times in the dendroclimatological record, as noted above. High seasonal variability, however, was unique, at the regional scale; that is, it happened only once, from 1250 to 1450. Note the slight but significant differences between the period of "high temporal variability" at $1350-1560$ and the episode of high seasonal variability at 1250-1450, and particularly the difference between the inceptions of each, at 1350 and at 1250 . While "high temporal variability" (i.e., unpredictability) in tree-ring departures began about 1350 , significant unpredictability in seasonal precipitation patterns began about 1250 . There is, of course, no reason why the two should coincide; the point here is that two different kinds of resource unpredictability are indicated that, in tandem, suggest an inclusive episode of significant resource unpredictability from 1250 to 1575 caused by both "high temporal" and chaotic seasonal variability. Thus, in combination, the indicated periods of resource unpredictability from both causes become: $310-380,750-1000$, $1250-1560$, and 1730-1825.

\section{Violence and Warfare}

Against periods of resource unpredictability, as defined above, we can contrast data from Steven LeBlanc's (1999) survey of Prehistoric Warfare in the American Southwest. LeBlanc defined three periods of warfare in the ancient Southwest: Early (0-900), Middle (900-1150), and Late (1250-Spanish contact). The missing "interim" period 1150-1250 was "particularly difficult to character- ize in terms of warfare" (LeBlanc 1999:153); I will return to the $1150-1250$ period below. LeBlanc characterized these periods by labels: Early, "Endemic warfare"; Middle, "Pax With a Twist"; and Late, "Crisis and Catastrophe" (LeBlanc 1999).

A wide range of behaviors is subsumed by terms such as "warfare" and "violence." LeBlanc refers to violence in both Early and Late periods as warfare. I prefer terms reflecting the very different nature of violence in those two periods (congruent with LeBlanc's presentation): in the Early period, a lower level of raiding and feuding, comprising sporadic, situational, tit-for-tat conflicts on a family or smallgroup scale; and in the Late period, real war, consisting of large, intense, institutionalized combat on village or even multiple-village scales. Yet a third form of violence characterized the Middle period: executions. These executions were the grim "twist" in LeBlanc's "Pax with a twist." All three forms of violence will be discussed at more length, below.

LeBlanc's Early period was marked by intermittent but persistent violence: endemic raiding and feuding. The severity of this violence was not constant through the Early period. LeBlanc notes that, within the long Early period (0-900), there was marked "increase in the level of warfare during the late Pueblo I period-in the late 700s and 800 s" (LeBlanc 1999:145). I therefore divide LeBlanc's long Early period into two subperiods, 0 to late $700 \mathrm{~s}$ and late 700 s to 900 , with increased evidence for raiding- and feuding-scale violence during the later subperiod. "It is unclear, at this point, why the rate of warfare intensified at that time [late 700s] or why it was so abruptly terminated [about 900]" (LeBlanc 1999:146). Neither of my changes-substituting "feuding and raiding" for LeBlanc's "endemic warfare" and the temporal recognition of intensified violence during the late ${ }^{-\cdots}$; - alters LeBlanc's general characterizations anu wnclusions about the Early period.

For his Middle period, LeBlanc amends my old phrase "Pax Chaco" to "Pax with a twist"-and there was indeed a "twist" (executions, discussed at length below). Otherwise, the Middle period from 900 to 1150 was "an era of unprecedented peace" (LeBlanc 1999:196). A wide range of archaeological data, summarized by LeBlanc, strongly suggests an abrupt and dramatic end to Early period raiding. In the Middle period, few homes were burned and violent trauma is rare. Middle period settlement can be fairly 
characterized as small single-family or extended family homes, scattered around the countryside in nondefensive locales. Often, these were loosely clustered in communities around Chaco "outliers," but this settlement pattern does not suggest concern for war

or violence. In summary, LeBlanc's Middle period was characterized by the absence of warfare and the presence of peace-but not the absolute absence of violence (as described below) from 900 to 1150 .

Middle period peace probably persisted beyond 1150 , through the hazy "interim" period from 1150 to1250. LeBlanc states, of this interim period, that violence was "present, but barely visible in the archaeological record," compared to spectacularly evident warfare after 1250 (LeBlanc 1999:195). Low visibility, I think, represents low occurrence: the interim was, from the evidence, largely an extension of the Pax Chaco. As I will argue below, political patterns that characterized Chaco from about 900 to 1125 continued at Aztec Ruins from about 1110 to 1275-throughout the interim period. The "Pax Chaco" continued, I think, as a failed "Pax Aztec." Therefore, I will extend the Middle period through the 1150-1250 "interim": for this paper, the Middle period dates from 900 to 1250 . I do not think my extension of LeBlanc's Middle period alters his recognition of a remarkable episode in southwestern prehistory. LeBlanc rightly concludes that the Middle period- "ten generations of a virtual absence of war, ... worthy of serious study"- -was an exceptional event (LeBlanc 1999:313). Adding several more generations of peace makes the Middle period even more remarkable.

In contrast to this remarkable era of peace, LeBlanc defines a limited but very specific form of violence that characterized the Middle period and accompanied the Pax Chaco. Against the absence of warfare in the Middle period, LeBlanc notes the presence of a disturbing form of social violence: a series of group executions recognized over much of the northern Pueblo area between the late 900 s and 1250 by LeBlanc (1999:162-186), by Turner and Turner (1999), by White (1992), and by Kuckelman et al. (2000). (I am not aware of incidents of this type of violence in the southern Pueblo world in the Middle period.) While a few incidents of this type of violence are known before and after the Middle period, archaeological evidence indicates that these events were sharply concentrated in the Middle period.

This form of violence was limited in scope. Turner and Turner (1999) note only about 75 possible instances, and re-analysis may reduce this number (see Billman et al. 2000). While few in number, the events were spectacularly brutal. In LeBlanc's words: "the bodies of humans were treated the same as carcasses of animals" (LeBlanc 1999:172). Small groups of people were executed, dismembered, mutilated, and, less certainly, cannibalized. White describes the archaeological remains of these events at a small pueblo in southwestern Colorado, dated to ca. 1100:

Scattered "bone beds" were found in several locations on the site. There is a clear dichotomy between these remains [of about 30 individuals] and the intentional, primary burials [of two individuals]. Unlike the primary burials, there was no association or articulation of skeletal elements, and multiple individuals were mixed together in the scattered bone beds. It is inferred. that the fragmentation of these remains was not the result of sediment pressure because fragments of individual skeletal elements were found widely separated. ... Elements in the bone beds manifest burning and trauma. There is no evidence of purposive burial and no evidence of in situ burning [White 1992:52-53].

This pattern has been documented throughout the Northern San Juan region by Kuckelman et al. (2000:159): "these characteristics indicate that much of the violence during this time was intended to do more than simply kill people." Kuckelman and her colleagues refer to these situations as "extreme processing," which they abbreviate as "EP." These events require a label to differentiate them from raiding and warfare, and following their terminology, I will call these executions "EP Events."

While the brutal nature of EP Events is beyond doubt, claims of cannibalism remain controversial. No claims have been made for subsistence cannibalism; almost all authors who positively consider evidence of cannibalism (Billman et al. 2000; Kantner 1999; LeBlanc 1999; Turner and Turner 1999) argue that the violence that culminated in cannibalism was an instrument of political power: a tactic of terror or intimidation. Other archaeologists have suggested that Middle period EP Events might also reflect witchcraft executions, without cannibalism (Bullock 1998; Darling 1999; Dongoske et al. 2000; Walker 1998), a subject to which we will return below. For the purposes of this paper, the reality or nonreality of cannibalism is not important. 


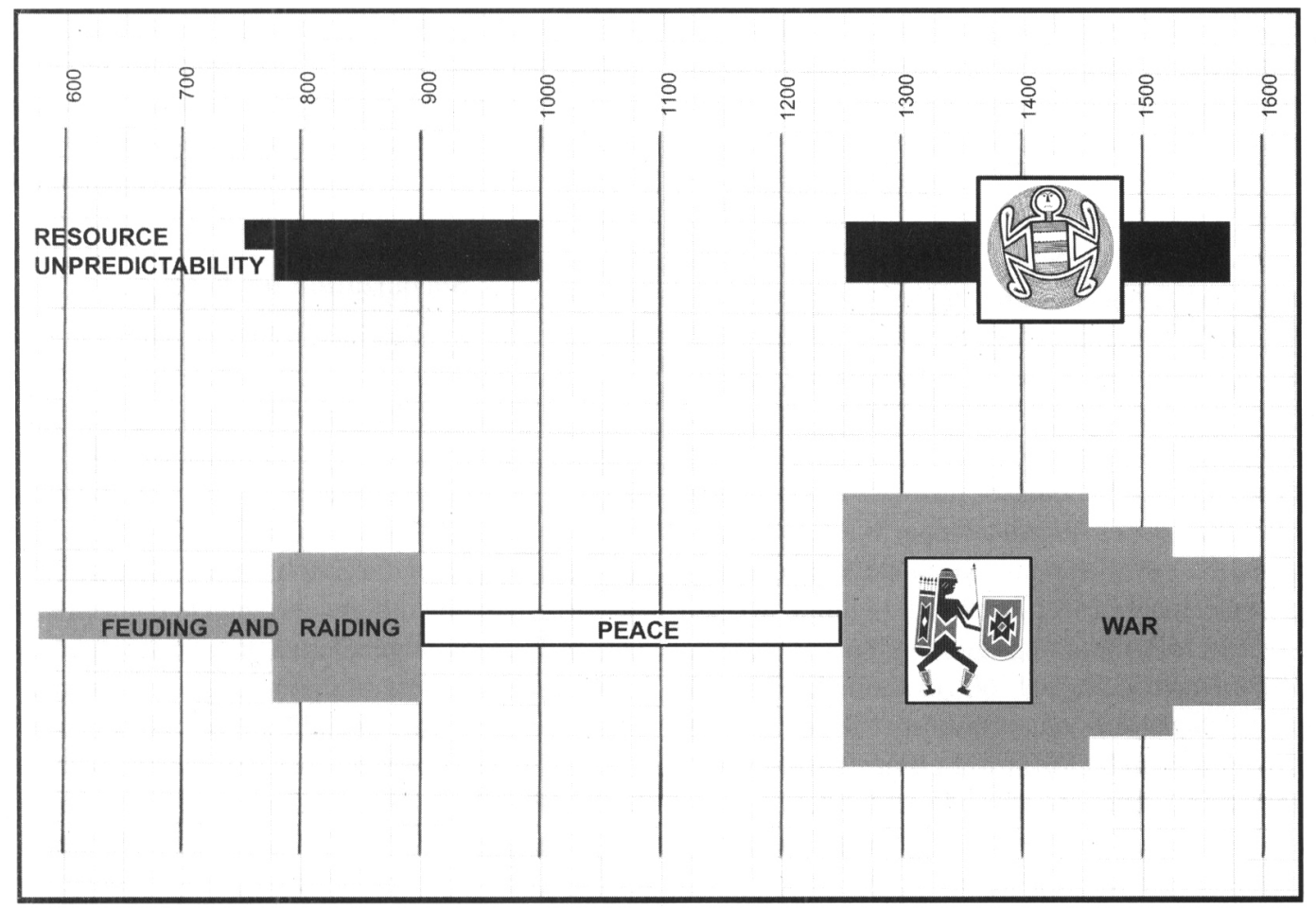

Figure 2. Schematic chronologies of resource unpredictability and violence. Periodization of resource unpredictability modified from Dean (1988, 1996); of raiding/feuding and warfare modified from LeBlanc (1999). See text for details. Note the approximate coincidence of periods of violence and periods of resource unpredictability and escalation of violence from raiding/feuding (early) to warfare (late).

LeBlanc's final Late period (1250-Spanish Contact) was marked by large-scale warfare: village against village and even multiple-village alliances against single villages or enemy alliances (see also Upham 1982). The scale and nature of southwestern violence reached levels that can appropriately be called warfare, in contrast to Early period raiding and feuding, and Middle period EP Events. LeBlanc sees large-scale warfare beginning in 1250 and continuing until Spanish Contact (which, hereafter, I date approximately to 1600) and beyond. It is notable that modern Pueblo stories and histories clearly recount warfare on dramatically larger scales during the Late period (Haas and Creamer 1997).

In summary, I recast LeBlanc's chronology (with my minimal revisions) thus:

0-late 700s early Early period Low-level raiding and feuding late $700 \mathrm{~s}-900$ late Early period Escalating raiding and feuding 900-1250 Middle period Peace with EP Events 1250-1600 Late period Village or alliance warfare

\section{Resource Unpredictability and Warfare, Compared}

With these chronologies in hand, we can evaluate the Ember and Ember model by comparing resource unpredictability with violence and warfare in the Pueblo Southwest (Figure 2). Recall that Dean defined four periods of "high temporal variability," which I have amended to incorporate Dean's (1996) era of high seasonal variability, thus: $310-380$, 750-1000, 1250-1560, and 1750-1825. Do these periods of resource unpredictability correspond to periods of warfare and violence? Taken in order,

310-380: Dean's first period of high temporal variability falls in the early part of LeBlanc's Early period (0-late 700s), for which there are few data. It is impossible to evaluate whether Dean's span of 310-380 corresponds to any increase against a background of what appears to be "endemic" low-level raiding and feuding.

750-1000: Dean's 750-1000 period of high temporal variability corresponds to the second part of 
LeBlanc's Early period (late 700s to 900 ), which was marked by a notable increase in the levels of feuding and raiding. There is a disjuncture of about one century between the end of Early period violence (at 900) and the end of high temporal variability (at 1000). We will revisit this disjuncture below.

1000-1250: The period from 1000 to 1250 was not marked by high resource unpredictability. It represents a 250-year span between two of Dean's periods of unpredictability. LeBlanc's peaceful Middle period (as extended by me to 900-1250) corresponds closely to this favorable climatic span, with the exception of the disjuncture mentioned above. The Middle period was "an era of unprecedented peace," punctuated by EP Events. Resource predictability and peace, therefore, co-occurred.

1250-1560: Dean's span of "high temporal variability" from 1350 to 1560 (expanded by me to include "high seasonal variability" from 1250 to 1450) corresponds closely to LeBlanc's Late period (1250-1600). The Late period was marked by village-on-village and alliance-on-alliance warfare"crisis and catastrophe," in LeBlanc's words.

1730-1825: LeBlanc does not extend his analysis beyond Spanish contact, so Dean's final period of "high temporal variability" is not applicable here. A brief survey of colonial history does not suggest a close correlation of high temporal variability and violence in the Spanish and Mexican Southwest. The Ember and Ember model, developed from non-state data, should not be expected to apply to the colonized Southwest after 1600 , with the possibility of bulk transportation of foodstuffs.

While not precise, the correspondences of LeBlanc's periods of Early period raiding, Middle period peace, and Late period warfare to Dean's periods of resource unpredictability are striking. Imprecision, in this comparison, should be evaluated in view of the nature of the two rather different chronologies: dendroclimatology is far more precise than cultural periodization. Moreover, "lag times" and temporal mismatches between causes and effects must be considered (and should be expected) in any model of past behaviors that are not completely mechanistic-people take time to react, and may react inappropriately or maladaptively to environmental change. I will argue, below, that the disjunctures have important implications for the second, psychological factor in the Ember and Ember model. For the present, however, comparison of LeBlanc's and Dean's analyses strongly support Ember and Ember's conclusion that resource unpredictability is a strong predictor of violence. Violence correlates well with resource unpredictably between 750 and 1600 in the Pueblo Southwest, as do peace and resource predictability.

\section{Socialization for Fear}

Resource unpredictability is an external or environmental cause of warfare and violence; many theorists (including Ember and Ember) argue for the importance of internal, psychological causes. The fit between resource unpredictability and violence, while close, is not chronologically precise. I believe that the observed disjunctures in the timing of resource unpredictability and violence have implications for internal predictors or causes.

In the Ember and Ember model, internal causes are psychological: socialization for fear. "Fear appears to be a common thread in the two obtained predictors of war-fear of nature and fear of others" (Ember and Ember 1992:256). Recall that Ember and Ember considered socialization "less strong" than resource unpredictability, but socialization for fear was still a significant predictor of war. Further, Ember and Ember argued that socialization for fear was, statistically and theoretically, a cause rather than a consequence of warfare. They discussed the relationship of resource scarcity and socialization for fear:

There is some evidence suggesting that fear of others may be at least partially a result of fear of resource scarcity; if people have a history of resource problems, their fear of scarcity may spill over into fear of others. In any case, mistrustful adults may be more likely to respond aggressively to the arousal of any fears, and therefore socialization for mistrust may lead to more war [Ember and Ember 1992:245].

How can we detect socialization for mistrust or fear, archaeologically? Socialization - "the process through which people and especially children are made to take on the ideas and behaviors appropriate to life in a particular society" (Toren 1996:512) occurs throughout the life cycle in all social settings, but childhood and family contexts are fundamental (e.g., Poole 1994). Family contexts are the domain of household archaeology. While household archaeology may prove useful in addressing this question, I look here for socialization as it might be institutionalized outside (above) the family and particularly in adult social contexts. These contexts could include 
ritual and ceremonial institutions (known to be important for socialization in modern Pueblos) and political institutions (perhaps more important in ancient Pueblo societies [Lekson 1999]). I focus here on the latter, and specifically on politically driven socialization. Politics is an adult occupation; war is politics by other means.

Recall that the nature of violence differed significantly from period to period. Early period violence was feuding and raiding. The Middle period was peaceful, but punctuated by EP Events. The Late period was characterized by widespread village-onvillage or alliance-on-alliance conflict. Early period and Middle period violence might not qualify as "war" under some definitions, but Late period violence was inarguably real warfare. Why did real warfare emerge during the Late period? The much higher escalated scale of Late period warfare may be related to socialization for mistrust or fear, particularly at the political level. To understand how this might have been so, I will digress briefly into a political history of the Pueblo Southwest. The chronology of political socialization for fear will then be compared to the nature of violence.

I have presented elsewhere (Lekson 1999) a political history of the Pueblo Southwest that, like any such broad-scale essay, is susceptible to criticism in detail. Various aspects of my argument may ultimately prove incorrect, but I believe that the larger patterns identified are consistent with the record as we now know it, and may well survive as reasonable readings of the past. I refer the reader to the original monograph (Lekson 1999) for the detailed argument and the data supporting it, which I summarize here.

There were, I argue, three sequential major regional centers or capitals of the Pueblo Southwest: Chaco (ca. 900-1125), Aztec Ruins (ca. 1110-1275), and Paquimé (ca. 1250 to1450) (Figure 1). Each center was the clear primate settlement of its place and time; each was the center of large but different regions. Chaco, Aztec, and Paquimé were, in Paul Wheatley's term, "ceremonial cities" (Wheatley 1971), but they were also, to varying degrees, political and economic centers. Through time (that is, from Chaco to Aztec to Paquimé) the basis of power shifted from strongly political to largely commercial. At the same time, the subsistence technologies supporting their near-urban populations (ca. 3,000-5,000 people) shifted from rainfall farming at Chaco, to small-scale irrigation at Aztec Ruins, to large-scale canal irrigation at Paquimé. The centers became increasingly self-reliant for subsistence support. I further argue that these three centers were historically linked, with the leaders of each referring symbolically to the preceding center for legitimation of power. That point, though interesting, is irrelevant to the present argument.

The political history corresponds reasonably well to the chronology of resource unpredictability and warfare, outlined above. Construction at Chaco begins about 900 (or even 850 [Windes and Ford 1996]). At about 900, two centuries of Early period intense raiding ended "abruptly" (LeBlanc's word). With the end of resource unpredictability at 1000 , Chaco expands to became a major regional center (ca. 1020; Judge 1989). The coincidence of the end of Early period feuding/raiding, the rise of Chaco, and changes in resource predictability is close, if not precise. The end of Chaco and the beginning of Aztec do not correspond to any major changes in resource unpredictability, and the nature of violence (EP Events in an era of peace) continues unchanged until the final decades of Aztec's span, a subject to which I will return below. The end of Aztec as a regional center and the rise, far to the south, of Paquimé corresponds well to the return of resource unpredictability and the explosion of warfare in the northern Pueblo world.

The nature of Chacoan polity is a matter of much debate. Judge (1989) and others see Chaco as a benign center of ritual and ceremony, but I argue that the evidence points to more formal, hierarchical political structure (Lekson 1999; see also Sebastian 1992). The reality of political power seems evident in Chaco's architecture and high-status burials, and Chacoan roads and outlier Great Houses suggest strong regional control. I suggest that, within the larger context of Pueblo history, Chaco represented a high degree of political centralization. Aztec Ruins, in my reconstruction, attempted to perpetuate Chacoan regional dominance, but with less success. Chaco was a relatively effective central political power; Aztec tried to be, but failed. Patterns of Middle period violence may provide insights on the nature of the Chaco and Aztec polities.

The Middle period peace prevailed from 900 to about 1250 , interrupted by several score EP Events of execution and mutilations. While I focus here on adult contexts, it is important to note that children were not immune from this violence: "The common 
inclusion of women and children that met violent death is an important characteristic of the violence in the Northern San Juan Region" (Kuckelman et al. 2000:153). I suggest that EP Events represent coercive force directed by and perhaps emanating first from Chaco and, later, from Aztec Ruins. Less than an army, but more effective than local villagers, forces from Chaco and (later) Aztec made brutal examples of families and households who, for whatever reasons, were deemed inimical to the Chaocan world order. This reconstruction is tame in comparison to Turner and Turner's (1999:480) "cannibal warrior cult" from Mexico, but consistent with the arguments of LeBlanc (1999) and Kantner (1999). As factors of politically driven socialization, it is reasonable to assume that knowledge of EP Events was widespread within and among communities; that is, everyone knew about the executions, and manychildren and adults - may have actually witnessed these brutal events.

This form of social violence might have been framed as witchcraft executions (Bullock 1998; Darling 1999; Dongoske et al. 2000; Walker 1998). If so, the Middle period witnessed an astonishing explosion of witchcraft. That attribution does negate the political implications of Middle period violence. Political power was almost certainly intertwined with religious and ceremonial systems. Political offenders might well have been condemned and punished as witches, or religious apostates, since an offense against the political power might also be seen as an offense against the ideological and ceremonial system. Parallels between the EP Events seen by LeBlanc and by Turner and Turner and socially sanctioned violence of historic Pueblo against witches might reflect punishments developed first for ancient crimes against the state (or at least against the polity), retained on later, smaller Pueblo village scales. I intend here no disrespect for Pueblo past (and present) with this discussion; I merely wish to communicate the possible comparability of Middle period EP Events and later witchcraft executions.

Middle period violence, I suggest, was institutionalized and controlled by central political authorities at Chaco and Aztec. It was a strong tool for enculturating "ideas and behaviors appropriate to life in a particular society" (that is, socialization) and for maintaining the structure of political power. EP Events occurred mainly (indeed, almost entirely) during the Middle period, and during a time other- wise remarkable for the absence of war and violence. Over the course of many decades, generations matured and reproduced amid general peace and economic prosperity, punctuated by rare but brutal EP Events, in which whole families and residence groups were executed and brutalized. Thus, Middle period violence constituted a dramatic socialization for fear, a topic to which I will return.

A central authority, I argue, was enforcing peace and social order by coercion, and EP Events are the most spectacular archaeological evidence of that coercive control. These were hierarchical political decisions, and therefore perhaps only distantly related to environmental perturbations. Indeed, EP Events were not correlated with or caused by resource unpredictability. I will argue that EP Events were politically driven, and their effects in socialization for fear was an important cause for elevated levels of warfare during the Late period.

\section{Socialization for Fear and Warfare, Compared}

Politically driven socialization for fear may be reflected in two intriguing chronological disjunctures, summarized here and discussed at more length below. First, a significant period of resource unpredictability ended about 1000 , while Early period violence ended and Chaco began about 900 , a century earlier. Second, construction at Aztec Ruins continued until at least 1275 (and perhaps even later), while a period of intense resource unpredictability and coincident Late period warfare began about 1250 , decades earlier.

The first disjuncture, between initial construction at Chaco and "Pax Chaco" at 900, and the end of resource unpredictability at 1000 , has implications for the noncorrelation of EP Events with resource unpredictability. Most scholars date the beginning of intense EP Events at about 900 (LeBlanc 1999; Kuckelman et al. 2000; Turner and Turner 1999). Large-scale construction also began at Chaco at or shortly before 900 . Neither EP Events nor the rise of Chaco appear to be coincident with the end of resource unpredictability, and instead both begin solidly within a period of high unpredictability.

According to an early (and unfairly discarded) model of Chacoan development (Judge 1979; Judge et al. 1981), Chaco arose about 900 as a cultural mechanism specifically to cope with resource unpredictability within the relatively small area of the San 
Juan Basin. That is, Chaco began as a small-scale political solution to problems of uneven food production within its immediate area (that is, the San Juan Basin). I argue elsewhere that, despite criticisms, this model for the tenth-century origins of Chaco remains valid (Lekson 1999; Malville 2001). That is, Chaco was a response to ongoing resource unpredictability, and it managed that unpredictability successfully for about a century (that is, from 900 to 1000). Chaco rose as a political solution to raiding and feuding caused (at least in part) by resource unpredictability. It appears likely that mechanisms of control included coercive force. Early period raiding and feuding ceased when EP Events of the Middle period began, and I do not believe the timing was coincidental.

Following Judge's (1989) chronology, Chaco expanded beyond the ecological limits of the San Juan Basin only after 1000; that is, after the 750-1000 episode of high temporal variability ended. Chaco's political structure, developed in the tenth century, evolved in remarkable ways after the onset of more favorable climatic conditions about 1000 . I believe the political system at Chaco was deliberately perpetuated and expanded beyond its original, environmental contexts. Mechanisms of political control developed to suppress raiding and feuding also continued in the improved environment of the Middle period: incidence of EP Events increased after 1000 (LeBlanc 1999; Kuckelman et al. 2000; Turner and Turner 1999). The shift in power from Chaco to Aztec was a political act (influenced by a short, twelfth-century drought, to be sure [Lekson 1999]), uncorrelated to resource unpredictability.

The onset of Late period village-scale warfare about 1250 correlates well with the reappearance of resource unpredictability, resulting from both chaotic seasonal variability and high temporal variability in rainfall (1250-1560). Large-scale construction, in contrast, continued at Aztec until 1275-the second temporal disjuncture. I argue that Aztec attempted to perpetuate Chaco's central political power and failed (Lekson 1999). The scale and scope of Aztec's political dominance never reached that of Chaco's; however, I believe Aztec's influence extended over most of the northern San Juan region. In the northern San Juan area, the period from 1150 to 1300 "includes fewer cases of extreme perimortem processing, [and relatively more] association of violent death with burned or partly burned structures, ante- mortem trauma, and at least one village-wide massacre. ... This violence could have been the result of escalating violence between sociopolitically equal settlement groups" (Kuckelman et al. 2000:159). At about 1250 , rainfall farming became increasingly problematic and intervillage warfare began.

The disjuncture between both the onset of war and resource unpredictability at 1250 contrasted to continued construction at Aztec until 1275 can be understood as evidence of political failure. The end of regional order does not result in the immediate abandonment of the center (consider Rome). Capitals are, by definition, important places and often overlap symbolically and temporally, and even spatially (Rapoport 1993). Old capitals are used in various ways to legitimize new capitals: the "new Rome," the "new Jerusalem," and so forth. There was, indeed, temporal overlap between the sequential centers which I construe to be capitals: the rise of the new center did not preclude continued construction at the prior center. This overlap should not surprise us: important places remain important, even in decline (or ruin). Construction continued at Aztec even after the natural and social environments began to deteriorate at 1250; leaders and decision makers did not have the benefit of our dendroclimatological retrodictions and did not realize that Aztec's run was over.

Political disintegration, environmental deterioration, and rising levels of warfare all surely contributed to the "abandonment" of the Four Corners. The details of that event, or series of events, are beyond the scope of this paper (see Duff and Wilshusen 2000; Lekson and Cameron 1995; Lipe 1995; Lipe and Varien 1999). It is important to note that the remarkable increase in intensity and scale of Late period violence after centuries of Middle period peace surely played a role in the totality and finality of the out-migration from the Four Corners area. At least 20,000 people left the Four Corners and joined existing communities in the areas of the modern Pueblos or created new towns in new places, as far south as modern Safford, Arizona and Magdalena, New Mexico (Wilson 1995; Woodson 1999). The population movements of 1250-1300 may have exacerbated environmental difficulties and escalated war's scale and intensity. In addition, those displacements created circumstances for sociopolitical change. The northern Pueblo area-once almost entirely subsumed in the Chacoan region-was characterized after 1250 by a breakdown of large-scale regional 
polities, and balkanized into a dozen smaller subregional traditions (Adler 1996; Lekson 1996). Nothing like Chaco or Aztec ever appeared again in the northern Pueblo world, from Hopi to the Rio Grande.

Sometime after 1200 , and probably about 1250 , a capital and political formation on the scale of Chaco and Aztec reappeared, but much farther south, at Paquimé in Chihuahua, Mexico. Paquimé's span from about 1250 to 1450 was remarkably coincident to the first half of LeBlanc's Late period (1250-1600) of village-on-village and alliance-on-alliance warfare across the northern Southwest. Paquimé probably traded with those northern villages, but I argue that Paquimé stayed out of the northern "troubles" (Lekson 1999). Paquimé was the third and final capital in my reconstruction of southwestern political history (Lekson 1999); but, far to the south, Paquimé's influence on contemporary northern Pueblos was probably far more commercial than political.

The Late period in the northern Pueblo world is accurately described by LeBlanc as a time of "crisis and catastrophe." The span 1250-1600 was marked by warfare on scales unprecedented in southwestern prehistory. Why did violence escalate to real war during the Late period? Why did Late period violence not return to the raiding and feuding that typified the Early period?

There were, of course, several important environmental and historical parameters that differed between the Early and Middle periods. Absolute population levels and regional densities were probably significantly higher in the Late period than in the Early period, although it is difficult to reach archaeological consensus in matters of population size (Adler 1996; Nelson et al. 1994). The nature of resource unpredictability had also changed: in addition to "high annual variability" from 1350 to 1575 , from 1250 to 1450 there was also a disruption of long-standing patterns of seasonal variability in precipitation, unique in dendroclimatological record (Dean 1996).

There were more people (probably) and harder times (certainly), but, against this, it appears that Late period Puebloan peoples adopted a wide range of new agricultural technologies and those technologies apparently worked: population is generally assumed to have continued to grow until the late fifteenth century. Whatever the causes of Late period warfare, those causes did not prevent Pueblo populations from increasing and, indeed, thriving. Fol- lowing the Ember and Ember model, I suggest that there were other, less-material factors influencing the severity of Late period warfare.

Psychological or internal causes may in part explain the intensification of warfare during the Late period: socialization for fear. Recall that Ember and Ember (1992) noted that this factor was "less strong" than resource unpredictability, but socialization for fear was still a highly significant predictor of war. Recall also that Ember and Ember argued that socialization for fear was, statistically and theoretically, a cause rather than a consequence of warfare (Ember and Ember 1992:245).

That conclusion may apply to the Late period, heir to the institutions and legacies of the Middle period. The Middle period was a period of peace, but it was marked by politically motivated socialization for fear: EP Events. I suggested that people knew (and were intended to know) about these events, and I assume that people learned (and were expected to learn) the social rules and contexts that provoked or caused them. EP Events were deliberate acts of socialization. The phrase EP Events is a sanitized term for truly horrible incidents. The killings were terrible: witch or political enemy, the victims were terrorized and brutalized. The events must have been as chilling and awful as political executions of twentieth-century nation-states. EP Events of Middle period suggest, almost inescapably, socialization for fear of old and young, adults and children. How could Puebloan people during the otherwise peaceful Middle period not live in fear-in fear of their own society? The causes of Middle period EP Events are of intense interest but, for evaluating the Ember and Ember model, they are to some degree irrelevant. Political "death squads" or witchcraft "inquisitions": the constant threat of socially sanctioned violence-whatever its source--would almost certainly create a climate of mistrust and fear.

Returning to Ember and Ember's model, recall that socialization for fear predicted warfare rather than the reverse. Recall also that the end of the Middle period was also the end of centralized political control in the northern Pueblo world. The strong central role of Chaco was diminished in its successor, Aztec; and by about 1250, Aztec had ceased to be an effective regional center. Socialization for fear, which had effectively controlled raiding and warfare. gave way to large-scale village warfare, far more violent than the endemic raiding and feuding of the 


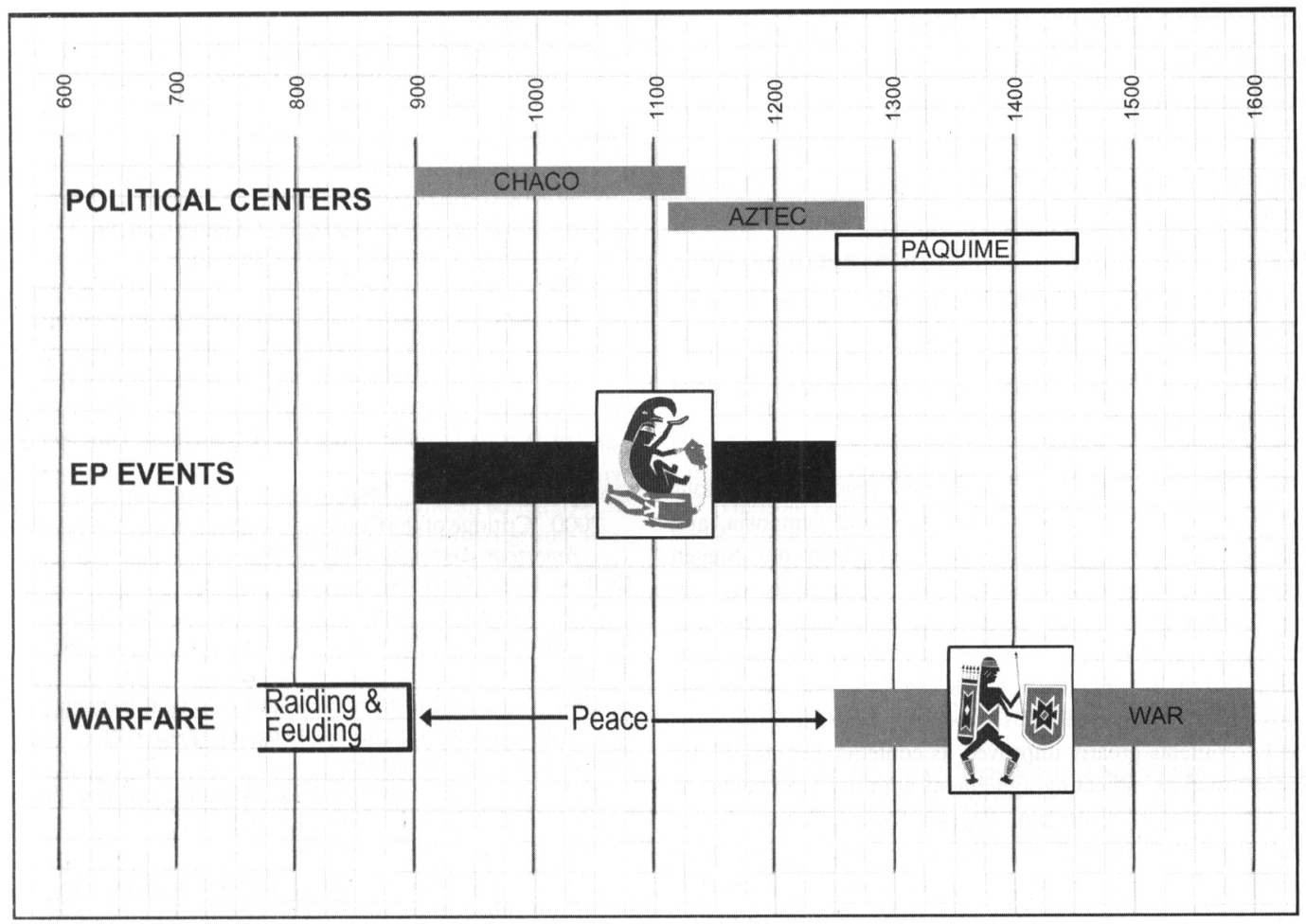

Figure 3. Schematic chronologies of political history, EP Events, and warfare. Northern centers are shown in gray, southern center shown in white. EP Events modified from LeBlanc (1999), Turner and Turner (1999), and Kuckelman et al. (2000). See text for details. Note that village-on-village and alliance warfare begins about 1250, approximately coincident with the eud of northern centers and "EP Events."

Early period (Figure 3 ). While there were other important factors (e.g., larger population and high seasonal variability, discussed above), it is worth considering socialization for fear as one cause of village-on-village warfare in the Late period. Three and one-half centuries of Middle period EP Events must have produced lasting cultural patterns-internal causes-that exacerbated and escalated warfare in the Late period. When Aztec ceased to function as a regional center, the political controls that had enforced peace in the Middle period disappeared and violence erupted on unprecedented levels: real war came to the Southwest.

A frequent criticism of cross-cultural analyses, such as the Ember and Ember study used here, is the general absence of history or sequence, and the consequent confusion of cause and effect. Does war cause fear, or does fear cause war? The chronology of violence and politics in the northern Pueblo world supports, to a degree, Ember and Ember: the increased intensity of warfare in the Late period was conditioned by the history, institutions, and psychology of the Middle period-the Pax Chaco with its politically driven use of political force-and the cultural legacy of over three centuries of socialization for fear.

\section{Conclusions}

How might the emerging recognition and study of violence in southwestern prehistory contribute to larger anthropological questions of warfare? Alone, lurid and controversial stories of cannibalism add little of value. Set within larger histories of politics, warfare, and ideology, the new southwestern data may, in fact, have something to contribute.

Steven LeBlanc in Prehistoric Warfare in the American Southwest differentiates theories about war that are fundamentally "materialist" versus those that are "nonmaterialist" (LeBlanc 1999:308ff.), closely paralleling Ember and Ember's "external" and "internal" categories. Among the former, we would find theories built around resource scarcity or evolutionary fitness; "nonmaterialist" theories, on the other hand, emphasize psychological or ideological factors. Often, these approaches are seen as exclusive and contradictory. The application of the 
Ember and Ember study to the Southwest suggests the utility of both: resource unpredictably is external and materialist, while socialization for fear is internal and nonmaterialist. Together, these two factors may better explain warfare in the ancient Southwest than models emphasizing only one school of thought. Referring to a slightly different dichotomy, Lawrence Keeley (1996:17) notes "the anthropological debates about the causes of warfare may represent a classic case of unacknowledged complementarity."

Acknowledgments. War is a dismal study. I presented versions of this argument at various conferences and symposia, and audiences did not rejoice. Neither Jeff Dean nor Steven LeBlanc nor David Wilcox agree with my conclusions, but they all generously commented on early drafts. Carol and Melvin Ember also read early drafts and condoned my use of their research. T. J. Ferguson, Carla Van West, and two anonymous reviewers critiqued this paper for American Antiquity. Their comments greatly improved its contents, but should not be construed as indicating agreement with my arguments. At the University of Colorado, Payson Sheets, Arthur Joyce, Linda Cordell, Claudio Cioffi, Catherine Cameron, and Doug Bamforth all commented on early drafts. Timothy Kohler, editor of American Antiquity, was remarkably helpful in seeing this manuscript through to publication. To all these friends and colleagues: thanks!

\section{References Cited}

Adler, M. A. (editor)

1996 The Prehistoric Pueblo World A.D. 1150-1350. University of Arizona Press, Tucson.

Ahlstrom, R. V. N., C. R. Van West, and J. S. Dean

1995 Environmental and Chronological Factors in the Mesa Verde-Northern Rio Grande Migration. Journal of Anthropological Archaeology 14:125-142.

Benedict, $\mathrm{R}$.

1989 [1934] Patterns of Culture. Houghton Mifflin, Boston.

Billman, B. R., P. M. Lambert, and B. L. Leonard

2000 Cannibalism, Warfare, and Drought in the Mesa Verde Region during the Twelfth Century A.D. American Antiquity $65: 145-178$.

Bullock. P. Y.

1998 Does the Reality of Anasazi Violence Prove the Myth of Anasazi Cannibalism? In Deciphering Anasazi Violence, edited by P. Y. Bullock, pp. 35-51. HRM Books, Santa Fe, New Mexico.

Cordell, L. S.

1994 Ancient Pueblo People. St. Remy Press, Montréal.

1996 Models and Frameworks for Archaeological Analysis of Resource Stress in the American Southwest. In Evolving Complexity and Environmental Risk in the Prehistoric Southwest, edited by J. A. Tainter and B. Bagley Tainter, pp. 251-265. Addison Wesley, Reading, Massachusetts.

1997 Archaeology of the Southwest. 2nd edition. Academic Press, San Diego.

Crown, P. L., and W. J. Judge (editors)

1991 Chaco and Hohokam. School of American Research Press, Santa Fe, New Mexio.
Darling, J. A.

1999 Mass Inhumation and the Execution of Witches in the American Southwest. American Anthropologist 100:732-752.

Dean, J. S

1988 Dendrochronology and Paleoenvironmental Reconstruction on the Colorado Plateau. In The Anasazi in a Changing Environment, edited by G. J. Gumerman, pp. 119-167. Cambridge University Press, Cambridge.

1996 Demography, Environment, and Subsistence Stress. In Evolving Complexity and Environmental Risk in the Prehistoric Southwest, edited by J. A. Tainter and B. Bagley Tainter, pp. 25-56. Addison-Wesley, Reading, Massachusetts.

Di Peso, C. C

1974 Casas Grandes. Amerind Foundation, Dragoon, Arizona.

Dongoske, K. E., D. L. Martin, and T. J. Ferguson

2000 Critique of the Claim of Cannibalism at Cowboy Wash. American Antiquity 65:179-190.

Duff, A. J., and R. H. Wilshusen

2000 Prehistoric Population Dynamics in the Northern San Juan Region, A.D. 950-1300. The Kiva 66:167-190.

Ember, $\mathrm{M}$.

1982 Statistical Evidence for an Ecological Explanation of Warfare. American Anthropologist 84:645-649.

Ember, C. R., and M. Ember

1992 Resource Unpredictability, Mistrust, and War. Journal of Conflict Resolution 36:242-262.

Ember, M., and C. R. Ember

1995 Worldwide Cross-Cultural Studies and Their Relevance for Archaeology. Journal of Archaeological Research 3:87-111.

Ferguson, R. B.

1984 Introduction: Studying War. In Warfare, Culture and Environment, edited by R. B. Ferguson, pp. 1-81. Academic Press, Orlando.

Ferguson, T. J., and E. R. Hart 1985 A Zuni Atlas. University of Oklahoma Press, Norman. Ferrill, A.

1997 The Origins of War: From the Stone Age to Alexander the Great. Westview Press, Boulder, Colorado.

Frazier, K

1999 People of Chaco. 2nd edition. W.W. Norton, New York.

Gumerman, G. J. (editor)

1988 The Anasazi in a Changing Environment. Cambridge University Press, Cambridge.

Haas, J. (editor)

1990 The Anthropology of War. Cambridge University Press, Cambridge, U.K.

Haas, J., and W. Creamer

1993 Stress and Warfare Among the Kayenta Anasazi of the Thirteenth Century A.D. Fieldiana, Anthropology New Series 21. Field Museum of Natural History, Chicago.

1997 Warfare Among the Pueblos. Ethnohistory 44:235-261.

Judge, W. J.

1979 The Development of a Complex Cultural Ecosystem in the Chaco Basin, New Mexico. In Proceedings of the First Conference on Scientific Research in the National Parks, edited by R. M. Linn, pp. 901-906. National Park Service, Washington, D.C.

- 1989 Chaco-San Juan Basin. In Dynamics of Southwest Prehistory, edited by L. S. Cordell and G. J. Gumerman, pp. 209-261. Smithsonian Institution Press, Washington, D.C.

Judge, W. J., W. B. Gillespie, S. H. Lekson, and H. W. Toll III

1981 Tenth-century Developments in Chaco Canyon. In Collected Papers in Honor of Erik Kellerman Reed, edited by 
A. H. Schroeder, pp. 65-98. Papers of the Archaeological Society of New Mexico 6. Archaeological Society of New Mexico, Albuquerque.

Kantner, J,

1999 Survival Cannibalism or Sociopolitical Intimidation? Human Nature 10:1-50.

Keeley, L. H.

1996 War Before Civilization. Oxford University Press, New York.

Kelly, R. C.

2000 Warless Societies and the Origin of War. University of Michigan Press, Ann Arbor.

Kohler, T. A., and C. R. Van West

1996 The Calculus of Self-Interest in the Development of Cooperation: Sociopolitical Development and Risk Among the Northern Anasazi. In Evolving Complexity and Environmental Risk in the Prehistoric Southwest, edited by J. A. Tainter and B. Bagley Tainter, pp. 169-196. Addison-Wesley, Reading, Massachusetts.

Kroeber, C. B., and B. L. Fontana

1986 Massacre on the Gila: An Account of the Last Major Battle Between American Indians, With Reflections on the Origin of War. University of Arizona Press, Tucson.

Kubler, G.

1962 The Shape of Time. Yale University Press, New Haven.

Kuckelman, K. A., R. R. Lightfoot, and D. L. Martin

2000 Changing Patterns of Violence in the Northern San Juan Region. The Kiva 66:147-165.

LeBlanc, S. A.

1999 Prehistoric Warfare in the American Southwest. University of Utah Press, Salt Lake City.

Lekson, S. H.

1996 The Pueblo Southwest After A.D. 1150. In Interpreting Southwestern Diversity, edited by P. R. Fish and J. J. Reid, pp. 41-44. Anthropological Research Paper 48. Arizona State University, Tempe.

1999 The Chaco Meridian. Altamira Press, Walnut Creek, California.

I.ckson, S. H., and C. M. Cameron

1995 The Abandonment of Chaco Canyon, the Mesa Verde Migrations, and the Reorganization of the Pueblo World. Journal of Anthropological Archaeology 14:184-202.

Lekson, S. H., J. R. Stein, T. Windes, and W. James Judge

1988 The Chaco Canyon Community. Scientific American 259:100-109.

Lipe, W. D.

1995 The Depopulation of the Northern San Juan: Conditions in the Turbulent 1200s. Journal of Anthropological Archaeology 14:143-169.

Lipe, W. D., and M. D. Varien

1999 Pueblo III (A.D. 1150-1300). In Colorado Prehistory: A Context for the Southern Colorado River Basin, edited by W. D. Lipe, M. D. Varien, and R. H. Wilshusen, pp. 290-352. Colorado Council of Professional Archaeologists, Denver.

Lister, R. H., and F. C. Lister

1981 Chaco Canyon. University of New Mexico Press, Albuquerque.

1987 Aztec Ruins on the Animas. University of New Mexico Press, Albuquerque.

Malville, Nancy J.

2001 Long-Distance Transport of Bulk Goods in the Prehispanic American Southwest. Journal of Anthropological Archaeology 20:230-243

McKenna, P. J., and H. W. Toll III

2001 Regional Patterns of Great House Development Among the Totah Anasazi, New Mexico. In Anasazi Regional Orga- nization and the Chaco System, 2nd edition, edited by D. E. Doyel, pp. 133-143. Maxwell Museum of Anthropology Anthropological Papers No. 5. Maxwell Museum of Anthropology, Albuquerque.

Nelson, B. A., T. A. Kohler, and K. W. Kintigh

1994 Demographic Alternatives. In Understanding Complexity in the Prehistoric Southwest, edited by G. Gumerman and M. Gell-Mann, pp. 113-146. Addison-Wesley, Reading, Massachusetts.

Otterbein, K. F.

1973 The Anthropology of War. In Handbook of Social and Cultural Anthropology, edited by J. J. Honigmann, pp. 923-958. Rand McNally, Chicago.

1997 The Origins of War. Critical Review 11: 251-277.

Plog, S.

1997 Ancient Peoples of the American Southwest. Thames and Hudson, London.

Poole, F. J. P.

1994 Socialization, Enculturation, and the Development of Personal Identity. In Companion Encyclopedia of Anthropology, edited by T. Ingold pp 831-860. Routledge, London.

Preston, D.

1998 Cannibals of the Canyon. New Yorker 74(37):76-89.

Rapoport, A.

1993 On the Nature of Capital and Their Physical Expression. In Capital Cities, edited by J. Taylor, J. G. Lengelle, and C. Andrew, pp. 31-67. Carlton University Press, Ottawa.

Reid, J., and S. Whittlesey

1997 The Archaeology of Ancient Arizona. University of Arizona Press, Tucson.

Reyna, S. P., and R. E. Downs (editors)

1994 Studying War: Anthropological Perspectives. Gordon and Breach, Amsterdam.

Rice, G., and S. A. LeBlanc (editors)

2001 Deadly Landscapes: Case Studies in Prehistoric Southwestern Warfare. University of Utah Press, Salt Lake City.

Schaafsma, P.

2000 Warrior, Shield, and Star: Imagery and Ideology of Pueblo Warfare. Western Edge Press, Santa Fe, New Mexico.

Schaafsma, C. F., and C. L. Riley (editors)

1999 The Casas Grandes World. University of Utah Press, Salt Lake City.

Sebastian, L.

1992 The Chaco Anasazi: Sociopolitical Evolution in the Prehistoric Southwest. Cambridge University Press, Cambridge, U.K.

Tainter, J. A., and B. Bagley Tainter (editors) 1996 Evolving Complexity and Environmental Risk in the Prehistoric Southwest. Addison-Wesley, Reading, Massachusetts.

Toren, C.

1996 Socialization. In Encyclopedia of Social and Cultural Anthropology, edited by A. Banard and J. Spencer, pp. 512-514. Routledge, London.

Turner, C. G., II 1999 A Reign of Terror. Discovering Archaeology 1:48-51.

Turner, C. G., II, and J. A. Turner 1999 Man Com. University of Utah Press, Salt Lake City.

Upham, S.

1982 Polities and Power. Academic Press, New York.

Van West, C. R.

1996 Agricultural Potential and Carrying Capacity in southwestern Colorado, A.D. 901-1300. In The Prehistoric Pueblo WorldA.D. 1150-1350, edited by M. A. Adler, pp. 214-227. 
University of Arizona Press, Tucson.

Walker, W. H.

1998 Where Are the Witches of Prehistory? Journal of Archaeological Method and Theory 5:245-308.

Whalen, M. E., and P. E. Minnis

2001 Casas Grandes and Its Hinterland: Prehistoric Regional Organization in Northwest New Mexico. University of Arizona Press, Tucson.

Wheatley, $\mathrm{P}$.

1971 The Pivot of the Four Quarters. Aldine, Chicago.

White, T. D.

1992 Prehistoric Cannibalism at Mancos 5MTUMR-2346. Princeton University Press, Princeton.

Wilcox, D., and J. Haas

1994 The Scream of the Butterfly: Competition and Conflict in the Prehistoric Southwest. In Themes in Southwest Prehistory, edited by G. J. Gumerman pp. 211-238. School of
American Research Press, Santa Fe, New Mexico.

Wilson, J. P.

1995 Prehistory of the Gallinas Mountains, Socorro County. In Of Pots and Rocks: Papers in Honor of A. Helene Warren, edited by Meliha S. Duran and David T. Kirkpatrick, pp. 189-210. Papers of the Archaeological Society of New Mexico 21, Albuquerque.

Windes, T. C., and D. Ford

1996 The Chaco Wood Project: The Chronometric Reappraisal of Pueblo Bonito. American Antiquity 61:295-310.

Woodson, M. K.

1999 Migrations in Late Anasazi Prehistory: the Evidence from The Goat Hill Site. The Kiva 65:63-84.

Received June 8, 2001; Revised May 13, 2002; Accepted May 14, 2002.

\section{new perspectives on the Southwest}

\section{Landscape of the Spirits \\ Hohokam Rock Art \\ at South Mountain Park \\ Text by Todd W. Bostwick, \\ photographs by Peter Krocek}

The first book to cover ancient images in

Phoenix's South Mountains. Interpreta-

tions of petroglyphs are based on Native

American ethnographic accounts and

consider the most recent theories concerning shamanism and archaeoastronomy. "A major and long-awaited contribution to the study of rock art in the Southwest."-Henry D. Wallace $330 \mathrm{pp}$., 71 color plates, 288 line illus. $\$ 60.00$ cloth, $\$ 27.95$ paper

\section{Salado Archaeology of the Upper Gila, New Mexico \\ Stephen H. Lekson}

By combining analysis of the large whole-vessel collection at Dutch Ruin with the scientific excavation of Villareal II, a picture of Salado emerges that enables Lekson to evaluate previous competing theories and propose that Salado represents a major fourteenth-century migration of Pueblo peoples into the Chihuahuan deserts.

Anthropological Papers No. 67. 103 pp., 50 illus. $\$ 16.95$ paper

\section{The Lost Itinerary of Frank Hamilton Cushing Edited by Curtis M. Hinsley and David R. Wilcox}

This second installment of a multivolume work on the Hemenway Southwestern Archaeological Expedition focuses on a report written by Cushing on its origins and early months. Hidden in several archives for a century, the Itinerary is assembled and presented here for the first time to offer a vivid account of the first attempt at excavations in the Southwest. $400 \mathrm{pp} ., 41$ illus. $\$ 50.00$ cloth

\section{New Perspectives on Site Function and Scale of Cerro de Trincheras, Sonora, Mexico The 1991 Surface Survey \\ Maria O'Donovan}

Provides information on broad scale patterning of artifacts and architecture. Refuse indicating varying household involvement and controlled access to ritual areas suggest inequalities within social organization.

Distributed for the Arizona State Museum, ASM Archaeological Series No. 195. 150 pp., 33 illustrations, CD-ROM. \$17.95 paper 